\title{
Pituitary Adenylate Cyclase Activating Polypeptide Elicits Neuroprotection Against Acute Ischemic Neuronal Cell Death Associated with NMDA Receptors
}

\author{
Yuji Kaneko Julian P. Tuazon ${ }^{\mathrm{a}} \quad$ Xunming Jib,c Cesario V. Borlongan ${ }^{\mathrm{a}}$ \\ aCenter of Excellence for Aging and Brain Repair, Department of Neurosurgery and Brain Repair, \\ University of South Florida College of Medicine, Tampa, USA, bDepartment of Neurosurgery, Xuanwu \\ Hospital, Capital Medical University, Beijing, 'China-America Institute of Neuroscience, Xuanwu \\ Hospital, Capital Medical University, Beijing, China
}

\section{Key Words}

$\mathrm{PACAP} \cdot \mathrm{OGD} / \mathrm{R} \cdot \mathrm{NMDAR} \cdot$ Acute ischemic stroke $・$ Neuroprotection

\begin{abstract}
Background/Aims: The endogenous neurotrophic peptides pituitary adenylate cyclaseactivating polypeptides (PACAP-27/38) protect against stroke, but the molecular mechanism remains unknown. Methods: Primary rat neural cells were exposed to PACAP-27 or PACAP-38 before induction of experimental acute ischemic stroke via oxygen-glucose deprivationreperfusion (OGD/R) injury. To reveal PACAP's role in neuroprotection, we employed fluorescent live/dead cell viability and caspase 3 assays, optical densitometry of mitochondrial dehydrogenase and cell growth, glutathione disulfide luciferase activity, ELISA for high mobility group box 1 extracellular concentration, ATP bioluminescence, Western blot analysis of PACAP, NMDA subunits, apoptosis regulator $\mathrm{BCl}-2$, social interaction hormone oxytocin, and trophic factor BDNF, and immunocytochemical analysis of PACAP. Results: Both PACAP-27 and PACAP-38 (PACAP-27/38) increased cell viability, decreased oxidative stress-induced cell damage, maintained mitochondrial activity, prevented the release of high mobility group box1, and reduced cytochrome c/caspase 3-induced apoptosis. PACAP-27/38 increased the protein expression levels of BDNF, Bcl-2, oxytocin, and precursor PACAP. N-methyl-Daspartate receptor (NMDAR)-induced excitotoxicity contributes to the cell death associated with stroke. PACAP-27/38 modulated the protein expression levels of NMDAR subunits. PACAP-27/38 increased the protein expression levels of the GluN1 subunit, and decreased that of the GluN2B and GluN2D subunits. PACAP-27, but not PACAP-38, increased the expression level of the GluN2C subunit. Conclusion: This study provides evidence that PACAP regulated NMDAR subunits, affording neuroprotection after OGD/R injury.




\section{Cellular Physiology Cell Physiol Biochem 2018;51:1982-1995 \begin{tabular}{ll|l} 
and Biochemistry 10.1159/000495722 & $\begin{array}{l}\text { O } 2018 \text { The Author(s). Published by S. Karger AG, Basel } \\
\text { wuww.karger.com/cpb }\end{array}$ \\
\cline { 2 - 3 }
\end{tabular} \\ Kaneko et al.: PACAP Regulates NMDAR Subunits}

\section{Introduction}

Despite advances in the management and care of stroke, ischemic-reperfusion injury is still a major cause of mortality and morbidity [1,2]. Disease progression with stroke primarily involves a primary insult characterized by an infracted core, and subsequent formation of an ischemic penumbra, which over a subacute period remains as salvageable neuronal tissue, thereby amenable to therapeutic intervention $[2,3]$. Secondary cell death processes, including oxidative stress, can further exacerbate cell death in the penumbra limiting neuro-restoration. Oxidative stress has been implicated in the pathogenesis of many central nervous system (CNS) disorders, including Alzheimer's disease [4] and Parkinson's disease [5].

Pituitary adenylate cyclase-activating polypeptide (PACAP), the first isolated hypothalamic neuropeptide [6], is a highly conserved member of the VIP/secretin/glucagon peptide family. PACAP exerts neurotrophic and neuromodulating effects, and exists as two biologically active forms: PACAP-38 and PACAP-27, which is produced by proteolytic cleavage of PACAP-38 [7]. PACAP-38 is the predominant form found in the brain, and PACAP-27 constitutes a minority, approximately $10 \%$, of total brain PACAP content [8]. Both PACAP-27 and PACAP-38 (PACAP-27/38) exhibit anti-inflammatory $[9,10]$ and neuroprotective properties mediated through the PAC1 receptor (PAC1R), which is associated with the G-protein coupled signaling pathway via adenylate cyclase [11]. However, the mechanisms underlying PACAP-induced neuroprotection against stroke are still elusive.

The $N$-methyl-D-aspartate receptor (NMDAR) is a glutamate-gated ion channel that is critically involved in physiological and pathological functions in the CNS [1]. NMDAR is activated by allosteric modulation and is composed of seven subunits: the GluN1 subunit, four distinct GluN2 subunits (GluN2A, GluN2B, GluN2C, and GluN2D), and a pair of GluN3 subunits (GluN3A and GluN3B). NMDARs function as heterotetrameric assemblies that typically associate two GluN1 subunits with the same two GluN2 subunits or a mixture of GluN2 (for example, 2GluN1/2GluN2A or 2GluN1/GluN2A/GluN2B). In the CNS, particularly cortex and hippocampus, GluN2A and GluN2B are the predominant subunits. The GluN2A subunitcontaining NMDAR in the synaptic cleft activates pro-survival signaling pathways. During ischemic conditions, extracellular glutamate concentrations increase, and stimulation of the GluN2B-containing NMDAR in the extrasynaptic sites triggers excitotoxic neuronal cell death [1]. PACAP is upregulated in an NMDAR-dependent manner in cortical neurons after focal ischemia [12]. The equilibrium shift of NMDAR subunit expression pattern is a key control point for determination of receptor diversity of the neuronal plasma membrane. Conversely, an imbalance between inhibitory and excitatory neurotransmission after an ischemic insult creates an excessive secretion of NMDA-relevant molecules, selectively limiting the tracking of NMDARs. The subsequent reperfusion after ischemia exacerbates neuronal functions and causes massive brain injuries when oxygen-saturated and nutrient-rich blood suddenly returns to the lesion after a period of ischemia. Such pathological conditions are closely resembled by the oxygen-glucose deprivation/reperfusion (OGD/R) paradigm, making it suitable as an ischemic-stroke model in vitro.

In this study, we demonstrated that pretreatment of primary rat neuronal cells (PRNCs) with PACAP-27 or PACAP-38 resulted in robust neuroprotective effects under OGD/R conditions. We also showed that PACAP-27/38 shifted the expression patterns of NMDAR subunits in these cells. These observations provide evidence that PACAP-27/38 modulated NMDAR-mediated neuroprotective effects against acute ischemia-induced neuronal cell death. 


\section{Cellular Physiology Cell Physiol Biochem 2018;51:1982-1995 \begin{tabular}{l|l|l} 
and Biochemistry Published online: 1 December 2018 & $\begin{array}{l}\text { (c) } 2018 \text { The Author(s). Published by S. Karger AG, Basel } \\
\text { www.karger.com/cpb }\end{array}$ \\
\hline
\end{tabular}

\section{Materials and Methods}

\section{Cell culture and oxygen-glucose deprivation-reperfusion $(O G D / R)$ progression}

Primary rat neural cells (PRNCs; consisted of $40 \%$ neurons and $60 \%$ astrocytes) were obtained from BrainBits (E18 rat cortex). As described elsewhere [13], cells ( $4 \times 10^{4}$ cells/well) were suspended in $200 \mu \mathrm{l}$ Neural Medium (NbActive 4, BrainBits) containing $2 \mathrm{mM}$ l-glutamine and 2\% B27 in the absence of antibiotics and grown in poly-l-lysine-coated 96 -well plates at $37^{\circ} \mathrm{C}$ in humidified atmosphere containing $95 \% \mathrm{O}_{2}$ and $5 \% \mathrm{CO}_{2}$ in $40 \%$ of the neuron and $60 \%$ astrocyte cell population (determined immunocytochemically using vesicular glutamate tensmate-1) [13]. After 3 days in culture, PRNCs were exposed to $0.2 \mathrm{nM} \sim 1 \mu \mathrm{M}$ PACAP-27 (GeneScript, RP10334-0.5), $0.2 \mathrm{nM} \sim 1 \mu \mathrm{M}$ PACAP-38 (GeneScript, RP10335-0.5), $300 \mathrm{nM}$ PACAP-27 + $1 \mu \mathrm{g}$ / $\mathrm{ml}$ anti PACAP sheep polyclonal antibody (R and D Systems Cat\# AF6380, RRID: AB_10717691), $300 \mathrm{nM}$ PACAP-38 $+1 \mu \mathrm{g} / \mathrm{ml}$ anti PACAP sheep polyclonal antibody, $1 \mu \mathrm{g} / \mathrm{ml}$ anti PACAP sheep polyclonal antibody alone, and the absence of reagents (control) for 4 days at $37^{\circ} \mathrm{C}$. After 7 days in culture (Fig. 1), RPNCs were exposed to OGD as described previously [13]. The cells were initially exposed to OGD medium (glucose-free Dulbecco's Modified Eagle Medium), then placed in an anaerobic chamber containing $95 \% \mathrm{~N}_{2}$ and $5 \% \mathrm{CO}_{2}$ for $15 \mathrm{~min}$ at $37^{\circ} \mathrm{C}$ (preincubation), for $90 \mathrm{~min}$ at $37^{\circ} \mathrm{C}$ (culture medium pH $6.7 \sim 6.8$; mimicking the acidic environment of ischemic brain in vivo). OGD was terminated by adding $5 \mathrm{mM}$ glucose to medium and cell cultures were re-introduced to the regular $\mathrm{CO}_{2}$ incubator at $37^{\circ} \mathrm{C}$ for $2 \mathrm{~h}$ (reperfusion treatment). Control cells were incubated in the same buffer containing $5 \mathrm{mM}$ glucose at $37^{\circ} \mathrm{C}$ in a regular $95 \% \mathrm{O}_{2}$ and $5 \% \mathrm{CO}_{2}$ incubator.

\section{Measurement of cell viability}

Measurement of cell viability was performed using fluorescent live/dead cell assay and trypan blue exclusion method $[13,14]$. In accordance with OGD/R procedure, the cells were incubated with $2 \mu \mathrm{M}$ Calcein-AM and $4 \mu \mathrm{M}$ EthD-1 (Invitrogen, L3224) for $45 \mathrm{~min}$ at room temperature (RT) in the dark. After washing once with phosphate buffer saline (PBS), the green fluorescence of the live cells was measured by the Gemini EX plate reader (Ex/Em = 490/520; Molecular Devices). In addition, trypan blue (Gibco, 15250) exclusion method was conducted and mean viable cell counts were calculated in 16 randomly selected areas $\left(1 \mathrm{~mm}^{2}, \mathrm{n}=10\right)$ to reveal the cell viability. Briefly, within $5 \mathrm{~min}$ after adding trypan blue, we digitally captured under microscope (200×) 10 pictures (approximately 100 cells/picture) for each condition, then randomly selected 5 pictures, and counted the number of cells for each individual treatment condition. Normalized cell viability was calculated from the following equation: viable cells $(\%)=[1.00-$ (Number of blue cells / Number of total cells)] $\times 100$. To precisely calibrate the cell viability, the values were standardized from fluorescence intensity and trypan blue data.

\section{Measurement of mitochondrial activity and membrane potential}

Following cell culture, reduction of 3-(4, 5-dimethyl-2-thiazoyl)-2, 5-diphenyltetrazolium bromide (MTT; Roche, 11465007001) by mitochondrial dehydrogenases was used as a measure of mitochondrial activity as previously described [13]. The optical density of solubilized purple formazan was measured at $570 \mathrm{~nm}$ on the EnSpire plate reader (ParkinElmer). For the measurement of membrane potential, PRNCs

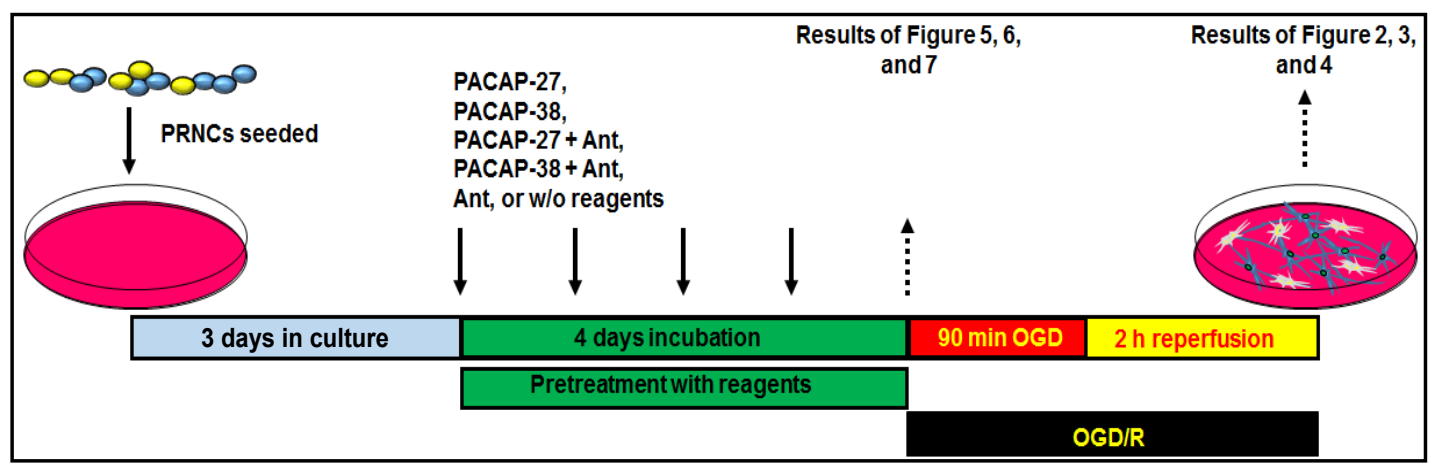

Fig. 1. Experimental design. PRNCs; primary rat neural cells. OGD; oxygen and glycose deprivation. Ant; Anti PACAP antibody. 


\section{Cellular Physiology Cell Physiol Biochem 2018;51:1982-1995 \begin{tabular}{l|l|l} 
and Biochemistry Published onlıne: 1 December 2018 & $\begin{array}{l}\text { (c) } 2018 \text { The Author(s). Published by S. Karger AG, Basel } \\
\text { www.karger.com/cpb }\end{array}$ \\
\hline
\end{tabular} \\ Kaneko et al.: PACAP Regulates NMDAR Subunits}

were incubated with $25 \mathrm{nM}$ tetramethylrhodamine methyl ester perchlorate (Sigma-Aldrich, T5428) for 45 min and the fluorescence intensity was measured by the Max Gemini EM plate reader.

Measurement of glutathione disulfide (GSSH) activity

Cells were treated with oxidized glutathione lysis reagent (Promega, V6611), and GSSG activity was measured by luciferase activity on the Max Gemini EM plate reader.

\section{Measurement of extracellular HMGB1 concentration}

After OGD/R treatment, the culture medium was centrifuged at 3,000 g, $4^{\circ} \mathrm{C}$ for $15 \mathrm{~min}$, and the supernatant was processed for HMGB1 releasing using ELISA kit (BlueGene, E02H0009) and the absorbance at $450 \mathrm{~nm}$ was measured on the EnSpire plate reader.

\section{Measurement of cell growth and ATP content}

Following cell culture, the cleavage of the tetrazolium salt, WST-1 (4-[3(4-lodophenyl)-2-(4nirtophenyl)-2H-5-tetrazolio]-1, 3-benzene disulfonate; Roche, 05015944011) formazan was used as a measure of cell growth. The optical density was measured at $450 \mathrm{~nm}$ on the EnSpire plate reader. The measurement of ATP content was analyzed using ATP bioluminescence assay kit (Roche, 11699709001) according to the manufacturer instructions. Luciferase reagent was added to the samples, and the luminescence was measured by the Max Gemini EM plate reader.

\section{Measurement of caspase 3 activity}

The caspase 3 activity was measured by caspase 3 assay kit (Abcam, ab39383) according to the manufacturer instructions. Cell lysate $(30 \mu \mathrm{g})$ was processed on DEVD-AFC substrate, and incubated at $37^{\circ} \mathrm{C}$ for $2 \mathrm{~h}$. The fluorescence of the caspase 3 activity was measured by the Max Gemini EM plate reader (Ex/Em $=400 / 505)$.

\section{Western blot analysis}

PRNCs were treated with CelLytic MT mammalian lysis reagent (Sigma-Aldrich, C3228) with protease inhibitor cocktail (Sigma-Aldrich, I3786). The lysate was centrifuged at 3,000 g, $4^{\circ} \mathrm{C}$ for $15 \mathrm{~min}$, and the supernatant was stored at $-80^{\circ} \mathrm{C}$ until analysis. Protein samples $(4 \sim 35 \mu \mathrm{g} / \mathrm{lane}$ ) were processed on $4 \sim 14 \%$ Tris-Glycine SDS-PAGE gel and then transferred onto a nitrocellulose membrane (Bio-Rad, 162-0112) at 30 $\mathrm{V}, 4^{\circ} \mathrm{C}$ for $14 \mathrm{~h}$. The nitrocellulose membranes were treated with PBS containing $0.1 \%$ Tween-20 (PBST) and 3\% non-fat milk (Bio-Rad, 170-6404) for 45 min at RT. Membranes were then incubated with the primary antibodies, anti Bcl-2 rabbit polyclonal (1/500, Abcam Cat\# ab115807, RRID: AB_10933855), anti oxytocin rabbit polyclonal (1/1,000, Abcam Cat\# ab67457, RRID: AB_1952293), anti BDNF rabbit monoclonal (1/1,000, Abcam, ab1083919), anti PACAP goat polyclonal (1/1,000, Abcam, ab223668), anti GAPDH mouse polyclonal (1/5,000, Abcam Cat\# ab8245, RRID: AB_2107448), anti $\beta$-tubulin rabbit polyclonal $(1 / 30,000$, Abcam Cat\# ab6046, RRID: AB_2210370), anti caspase 3 rabbit polyclonal (1/100, Abcam Cat\# ab4051, RRID: AB_304243), anti cleaved caspase 3 rabbit polyclonal (1/2,000, Sigma-Aldrich Cat\# C8487, RRID: AB_476884), anti GluN1 rabbit polyclonal (1/1,000, Abcam Cat\# ab109182, RRID: AB_10862307), and GluN2A rabbit polyclonal (1/1,000, Abcam, ab169873), anti GluN2B rabbit polyclonal (1/1,000, Abcam, ab565783), anti GluN2C rabbit polyclonal (1/1,000, Abcam Cat\# ab110, RRID: AB_297655), anti GluN2D rabbit polyclonal (1/1,000, Thermo Fisher Scientific Cat\# PA5-39190, RRID: AB_2555782), anti GluN3A rabbit polyclonal (1/1,000, Antibodies-Online Cat\# ABIN571959, RRID: AB_10787799) and anti GluN3B $(1 / 1,000$, Antibodies, $\mathrm{ABX} 135999)$ at $4^{\circ} \mathrm{C}$ for $14 \mathrm{~h}$. After washing with PBST, the nitrocellulose membrane was incubated with donkey anti mouse IRDye $800^{\circledR} \mathrm{CW}$ secondary antibody $(1 / 5,000$, LI-COR Biosciences Cat\# 926-32212, RRID: AB_621847), or donkey anti-rabbit IRDye800 ${ }^{\circledR} \mathrm{CW}$ secondary antibody $(1 / 5,000$, LI-COR Biosciences Cat\# 926-32213, RRID: AB_621848) for 90 min at RT in the dark. Immunoreactive detection using near-infrared fluorescence was performed according to the protocol of Odyssey ${ }^{\circledR}$ Infrared Imaging System (LI-COR ${ }^{\circledR}$ ). 


\section{Cellular Physiology Cell Physiol Biochem 2018;51:1982-1995 \begin{tabular}{ll|l} 
and Biochemistry Published online: 1 December 2018 & $\begin{array}{l}\text { @ } 2018 \text { The Author(s). Published by S. Karger AG, Basel } \\
\text { www.karger.com/cpb }\end{array}$ \\
\hline
\end{tabular} \\ Kaneko et al.: PACAP Regulates NMDAR Subunits}

\section{Immunocytochemistry analysis}

PRNCs $\left(8 \times 10^{4}\right.$ cell/well) were cultured in $400 \mu$ l Neural medium containing $2 \mathrm{mM}$ l-glutamine and $2 \%$ B27 in the absence of antibiotics in poly-l-lysine 8-chamber (BD Bioscience, 354632) for 3 days, then the cells were exposed to $300 \mathrm{nM}$ PACAP-27, or $300 \mathrm{nM}$ PACAP-38, or the absence of reagents (CONT) for 4 days and fixed in 4\% paraformaldehyde [13]. The cells were washed 5 times for $10 \mathrm{~min}$ in PBST. Then they were blocked by 5\% normal goat serum (Invitrogen, 50062Z) in PBST for $1 \mathrm{~h}$ at RT. Primary antibodies included anti cytochrome c rabbit monoclonal antibody (1/1,000, Abcam Cat\# ab76237, RRID: AB_1523454) and anti ATP synthase $\beta$ chain (mitochondria) (1/200, Cell Signaling Technology, 05-709). The cells were incubated overnight at $4{ }^{\circ} \mathrm{C}$ in primary antibody with $5 \%$ normal goat serum. The cells were washed 5 times for 10 min in PBST and then soaked in 5\% normal goat serum in PBST containing corresponding secondary antibodies goat anti rabbit IgG-Alexa 488 (green; 1/1,000, Invitrogen, A11034), and goat anti-mouse IgG-Alexa 594 (red; 1/1,000, Invitrogen, Cat\# A11032, RRID: AB_141672) for $90 \mathrm{~min}$ in the dark. Immunofluorescent images were visualized using a confocal microscope (FV1000, Olympus). Control experiments were performed with the omission of the primary antibodies yielding negative results.

\section{Data analysis}

Data were evaluated using one-way analysis of variance (ANOVA) followed by post hoc compromised t-tests (GraphPad Prism $6^{\circledR}$ software, RRID: SCR_002798). Statistical significance was preset at $P<0.05$. Data are represented as means \pm SD from quintuplicates of each treatment condition.

\section{Results}

\section{PACAP-27/38 exerts neuroprotection against OGD $/ R$}

As shown in Fig. 1, PRNCs were exposed to the OGD/R in vitro model of acute ischemic stroke $[13,15]$. Under $\mathrm{OGD} / \mathrm{R}$ conditions, PRNC viability was significantly decreased compared to control, which did not undergo OGD/R (Fig. 2A, CONT vs w/o, $P<0.001$ ). Cell viability was significantly increased in a dose-dependent manner with PACAP-27 and PACAP-38 administration; the estimated $E C_{50}$ values for cell viability were $35.7 \pm 1.68 \mathrm{nM}$ and $49.9 \pm 1.28 \mathrm{nM}$, respectively (Fig. $2 \mathrm{~A}$ ). The maximal neuroprotection of both PACAP-27 and PACAP-38 treatment was reached at $300 \mathrm{nM}$ (Fig. 2A). Following acute ischemic stroke experiments in vitro, PRNCs were cultured with $300 \mathrm{nM}$ PACAP-27 (PACAP-27), $300 \mathrm{nM}$ PACAP-38 (PACAP-38), or in the absence of reagent (w/o) for 4 days at $37^{\circ} \mathrm{C}$ before OGD (Fig. 1). To confirm that protection of cell viability under OGD/R depends on PACAP-27/38 treatment, we compared cell viability in the presence of the PACAP antibody (PACAP-27 + Ant and PACAP-38 + Ant; Fig. 2B) with PACAP-27 or PACAP-38 alone. Pretreatment with PACAP-27 and PACAP-38 significantly increased cell viability $\left(F_{(2,14)}=48.33, P<0.0001\right.$ and $F_{(2,19)}=30.38, P<0.0001$, respectively; Fig. $\left.2 \mathrm{~B}\right)$, and efficacy was abolished in the presence of PACAP antibody (Fig. 2B, $g$ vs $g$, and $h v s h$ ). PACAP-27/38 recovered mitochondrial activity $\left(F_{(2,23)}=64.74, P<0.0001\right.$ and $F_{(2,22)}=88.18, P<0.0001$, respectively; Fig. $\left.2 \mathrm{C}\right)$ and mitochondrial membrane potential $\left(F_{(2,35)}=28.13, P<0.0001\right.$ and $F_{(2,35)}=29.63, P<0.0001$, respectively; Fig. 2D), decreased glutathione disulfide (GSSG) activity $\left(F_{(2,21)}=69.04, P<\right.$ 0.0001 , and $F_{(2,21)}=69.97, P<0.0001$, respectively; Fig. $\left.2 \mathrm{E}\right)$, and prevented the secretion of high mobility group box1 (HMGB1), a mediator of ischemic progression $[15,16]$ from PRNCs (Fig. 2F). These results indicate that PACAP-27/38 elicited neuroprotection against OGD/R.

\section{PACAP-27/38 acts on the mitochondrial apoptotic pathway}

In ischemic conditions, reactive oxygen species (ROS) activate the mitochondrial apoptotic signaling pathway, which intermediates caspase 3 activation [17]. PACAP-27/38 administration significantly reduced the expression level of cleavage caspase $3(17 \mathrm{kDa}$, Fig. 3A, B) and its activity (Fig. 3C), although caspase 3 expression levels were similar between experimental groups (35 kDa, Fig. 3A, B). As caspase 3 is downstream of cytochrome c-mediated apoptotic signaling, we sought to determine whether PACAP-27/38 prohibited the release of cytochrome $c$ from mitochondria into the soluble cytoplasm (Fig. 4). In 


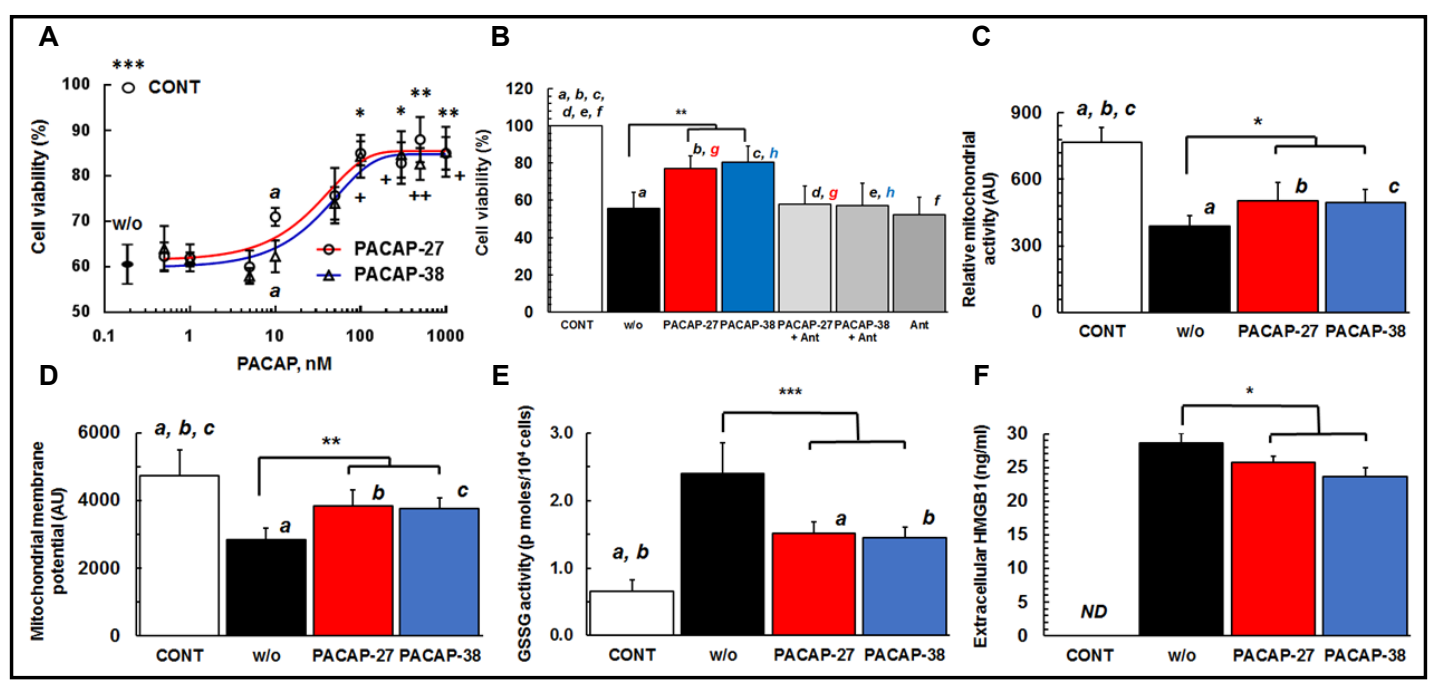

Fig. 2. PACAP-27 and PACAP-38 confer neuroprotective effects and attenuate the oxidative stress against OGD/R. (A) Dose-response effects on cell viability based on PACAP-27 and PACAP-38 concentration. The maximal neuroprotection of both PACAP-27 and PACAP-38 was reached at $300 \mathrm{nM}$. Following incubation of PRNCs in the absence of reagents (w/o), $300 \mathrm{nM}$ PACAP-27 (PACAP-27), and $300 \mathrm{nM}$ PACAP-38 (PACAP-38) for 4 days at $37^{\circ} \mathrm{C}$, PRNCs were performed with OGD/R treatment. Control PRNCs (CONT) were not performed with the OGD/R. a versus (vs) a P<0.05. (B) Anti PACAP antibody significantly reduced both PACAP-27 and PACAP-38 neuroprotective effects. Following incubation of PRNCs in the absence of reagents (w/o), $300 \mathrm{nM}$ PACAP-27, $300 \mathrm{nM}$ PACAP-38, $300 \mathrm{nM}$ PACAP-27 + $1 \mu \mathrm{g} / \mathrm{ml}$ anti PACAP antibody (PACAP-27 + Ant), $300 \mathrm{nM}$ PCAP-38 + $1 \mu \mathrm{g} / \mathrm{ml}$ anti PACAP antibody (PACAP-38 + Ant), and $1 \mu \mathrm{g} / \mathrm{ml}$ anti PACAP antibody (Ant) only for 4 days at $37^{\circ} \mathrm{C}$, PRNCs were performed with $0 G D / R$ treatment. a vs a $\mathrm{P}<0.001, \mathrm{~b}$ vs b $\mathrm{P}<0.001$, c vs c $\mathrm{P}<0.001$, $\mathrm{d}$ vs $\mathrm{d} \mathrm{P}<0.001$, e vs e $\mathrm{P}<0.001$, f vs f $\mathrm{P}<0.001$. (C) Mitochondrial activity by MTT assay. a vs a $P<0.001$, b vs b $P<0.001$, and c vs $c P<0.001$. (D) Mitochondrial membrane potential by TMRM assay. a vs a $\mathrm{P}<0.001$, b vs $\mathrm{b} \mathrm{P}<0.001$, and $\mathrm{c}$ vs $\mathrm{c} \mathrm{P}<0.001$. (E) GSSG activity by GSH/GSSG-Glo assay. a vs a $\mathrm{P}<0.001, \mathrm{~b}$ vs $\mathrm{b} P<0.001$, and $\mathrm{c}$ vs $\mathrm{c} \mathrm{P}<0.001$. (F) Extracellular HMGB1 levels by HMGB1 ELISA assay. a vs a $\mathrm{P}<0.001, \mathrm{~b}$ vs b $\mathrm{P}<0.001$, and c vs c $\mathrm{P}<0.001$. (C, D, E, F). ${ }^{*} \mathrm{P}<0.05$, ${ }^{* *} \mathrm{P}<0.01,{ }^{* * *} \mathrm{P}<0.001,{ }^{+} \mathrm{P}<0.05$, and ${ }^{++} \mathrm{P}<0.01$ vs $\mathrm{w} / \mathrm{o}$. Experiments were conducted in triplicate, with $\mathrm{n}=3 \sim 5$ per treatment condition in each run.

Fig. 3. PACAP-27 and PACAP-38 decreased both caspase 3-cleavage and -activity. Following incubation of PRNCs in the absence of reagents (w/o), 300 nM PACAP-27, and 300 nM PACAP-38 for 4 days at $37^{\circ} \mathrm{C}$, PRNCs were performed with OGD/R treatment. Control (CONT) was not performed with

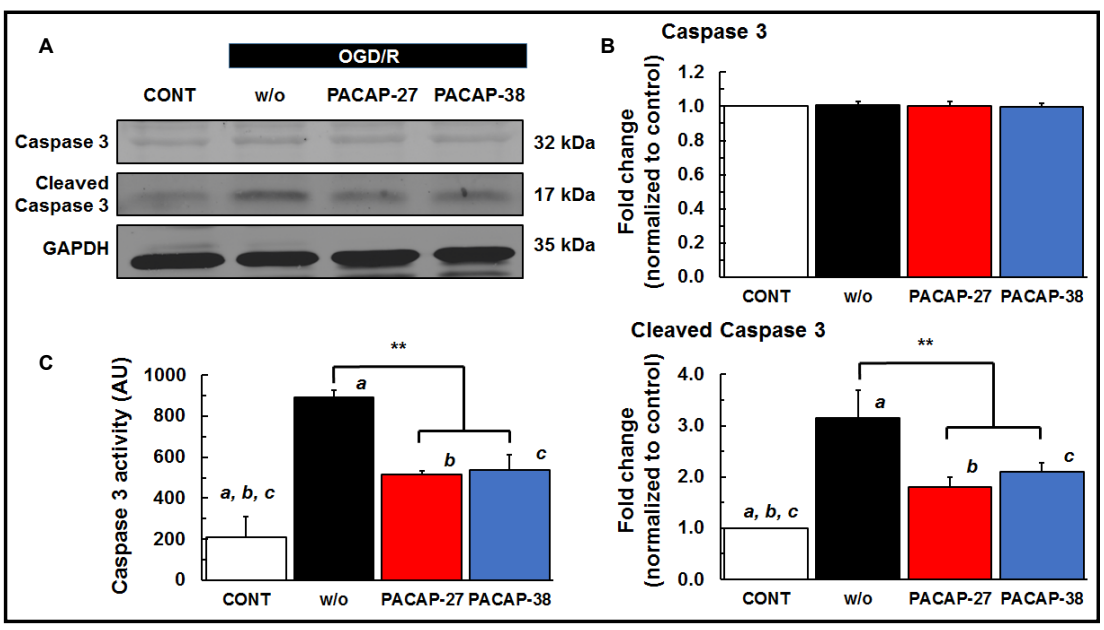
the OGD/R treatment.

(A) Western blot analysis. (B) Relative quantification of caspase 3 (top) and cleave caspase 3 (bottom). a vs a $\mathrm{P}<0.01$, b vs $\mathrm{b} \mathrm{P}<0.05$, and c vs c $\mathrm{P}<0.05$. (C) Caspase 3 activity. a vs a $\mathrm{P}<0.001$, b vs b $\mathrm{P}<0.01$, c vs c $\mathrm{P}<0.01$, and ${ }^{* *} \mathrm{P}<0.01$ vs $\mathrm{w} / \mathrm{o}$. Experiments were independently conducted $3 \sim 4$ times. 


\section{Cellular Physiology Cell Physiol Biochem 2018;51:1982-1995 and Biochemistry \begin{tabular}{l|l} 
DOI: 10.1159/000495722 & (c) 2018 The Author(s). Published by S. Karger AG, Basel \\
www.karger.com/cpb
\end{tabular}

Fig. 4. $P A C A P-27$ and PACAP-38 decrease the release of cytochrome c from mitochondria, which turns on the caspase 3-induced apoptotic signal pathway. Following incubation of PRNCs in the absence of reagents (w/o), 300 nM PACAP-27, and 300 nM PACAP-38 for 4 days at $37^{\circ} \mathrm{C}$, PRNCs were performed with

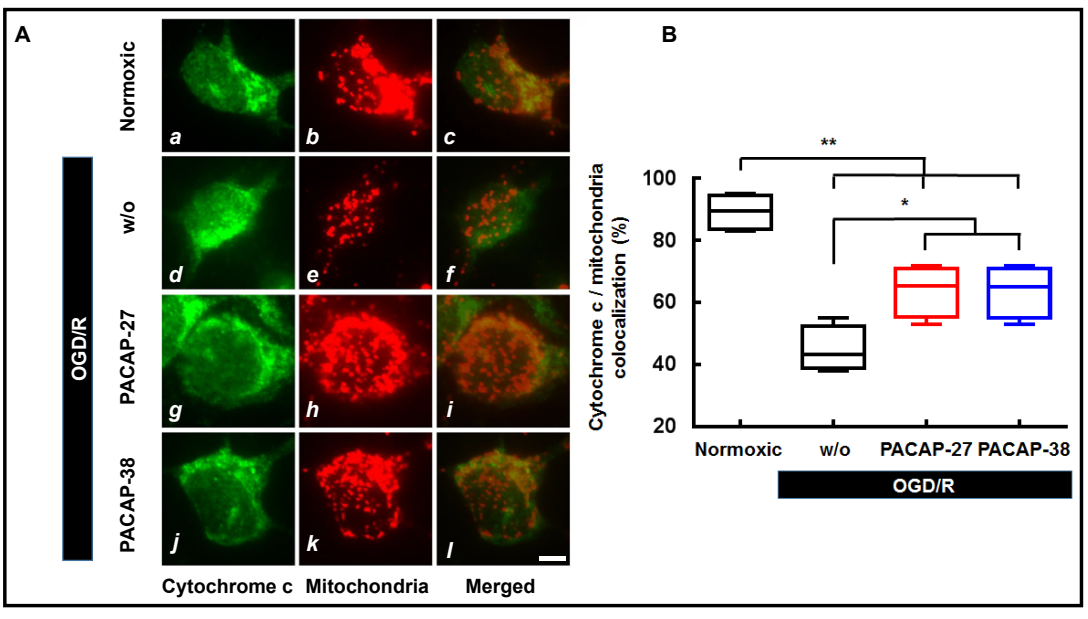
the OGD/R treatment.

Control (CONT) was not performed with the OGD/R treatment. (A) Immunocytochemistry analysis. Cytochrome c (a, d, g, and j) and mitochondria (b, e, h, and k) staining reveals an apparent maintained within the mitochondria under OGD/R condition when treated with $300 \mathrm{nM}$ PACAP-27 and PACAP-38 compared to without PACAP treatment (w/o). Cytochrome $\mathrm{c}$ and mitochondria double-positive cells are shown in panels. Green: cytochrome c, Red: mitochondria, scale bar $=5 \mu \mathrm{m}$. (B) Colocalization of cytochrome $\mathrm{c}$ and mitochondria was quantified independently 4 times. ${ }^{*} \mathrm{P}<0.01$ and ${ }^{* *} \mathrm{P}<0.01$.

normoxic conditions, cytochrome $\mathrm{c}$ was retained within the mitochondria (Fig. 4A $(a \sim c)$, B). Under the OGD/R condition, cytochrome $\mathrm{c}$ was released into the cytoplasmic area (Fig. 4A (d $\sim f$ ), B). When the cells were treated with PACAP-27/38, cytochrome $c$ remained within the mitochondria (Fig. $4 \mathrm{~A}(g \sim l), \mathrm{B})$.

\section{Biological activity readouts across treatments}

The following experiments were performed with PRNCs cultured with 300 nM PACAP-27 (PACAP-27), $300 \mathrm{nM}$ PACAP-38 (PACAP-38), and in the absence of reagent (CONT) for 4 days at $37^{\circ} \mathrm{C}$ (Fig. 1). PACAP-27/38 is related to cell growth pathways [18] and anti-inflammatory signaling $[9,10]$, suggesting its potential application in the treatment of neuronal diseases [19]. However, PACAP-27/38 administration did not alter cell growth (Fig. 5A) or ATP content (Fig. 5B) of PRNCs compared with control treatment (CONT). Next, because peripheral PACAP-27/38 participates in glucose metabolism and modulation of ROS production [20], we examined the effects of PACAP-27 and PACAP-38 on mitochondrial membrane potential and GSSG activity. PACAP-27/38 administration did not change the mitochondrial membrane potential (Fig. 5C) and GSSG activity (Fig. 5D) in comparison with control values (CONT).

\section{PACAP-27/38 increases neurotrophic factor expression}

PACAP-related neuroprotective effects are due to inhibition of apoptosis and reduction of oxidative stress [9]. We therefore assessed whether PACAP-27 and PACAP-38 modulated expression of neurotrophic factors. PACAP-27/38 administration significantly increased the protein expression levels of prototype brain-derived neurotrophic factor BDNF (proBDNF), mature BDNF (mBDNF), antiapoptotic protein Bcl-2 (B-cell lymphoma 2), oxytocin, and precursor PACAP, although the PAC1R expression levels were similar to control levels (Fig. 6).

\section{PACAP-27/38 shifts the NMDAR subunit expression patterns}

PACAP promotes survival of rat cortical neurons against glutamate-induced neuronal cell death [21] and modulates the components of NMDARs specific to glutamate [22,23]. We investigated whether PACAP-27 and PACAP-38 altered the expression patterns of NMDAR subunits (Fig. 7). PACAP-27/38 administration significantly increased GluN1 subunit 
Fig. 5. Effects of PACAP-27 and PACAP-38 treatment on biological activity before OGD. Following incubation of PRNCs in the absence of reagents (control; CONT), $300 \mathrm{nM}$ PACAP-27, and 300 nM PACAP-38 for 4 days at $37^{\circ} \mathrm{C}$, the biological activity was measured. PRNCs' cell growth. PACAP-27 and PACAP-38 had no significant effects on cell growth. (B) ATP contents. (C) Mitochondria membrane potential. (D) GSSG activity. GSSG is a biomarker of oxidative stress.

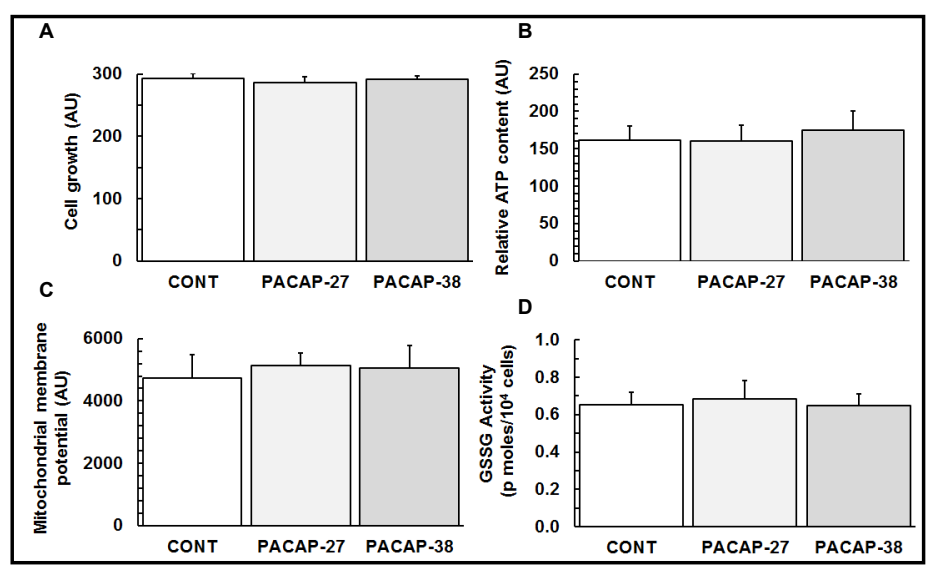
Experiments were conducted in triplicate, with $\mathrm{n}=5$ per treatment condition in each run.

Fig. 6. PACAP-27 and PACAP-38 enhanced neuroprotective factor expression. Following incubation of PRNCs in the absence of reagents (control; CONT), $300 \mathrm{nM}$ PACAP-27, and $300 \mathrm{nM}$ PACAP-38 for 4 days at $37^{\circ} \mathrm{C}$, Western blot was performed. (A) Western blot analysis. Relative quantification of protein expression levels. $\quad * * * \mathrm{P}<0.001$. Experiments were i $\mathrm{n} \mathrm{d}$ e p e $\mathrm{nd}$ e $\mathrm{n} \mathrm{t} \mathrm{ly}$ conducted $3 \sim 4$ times.

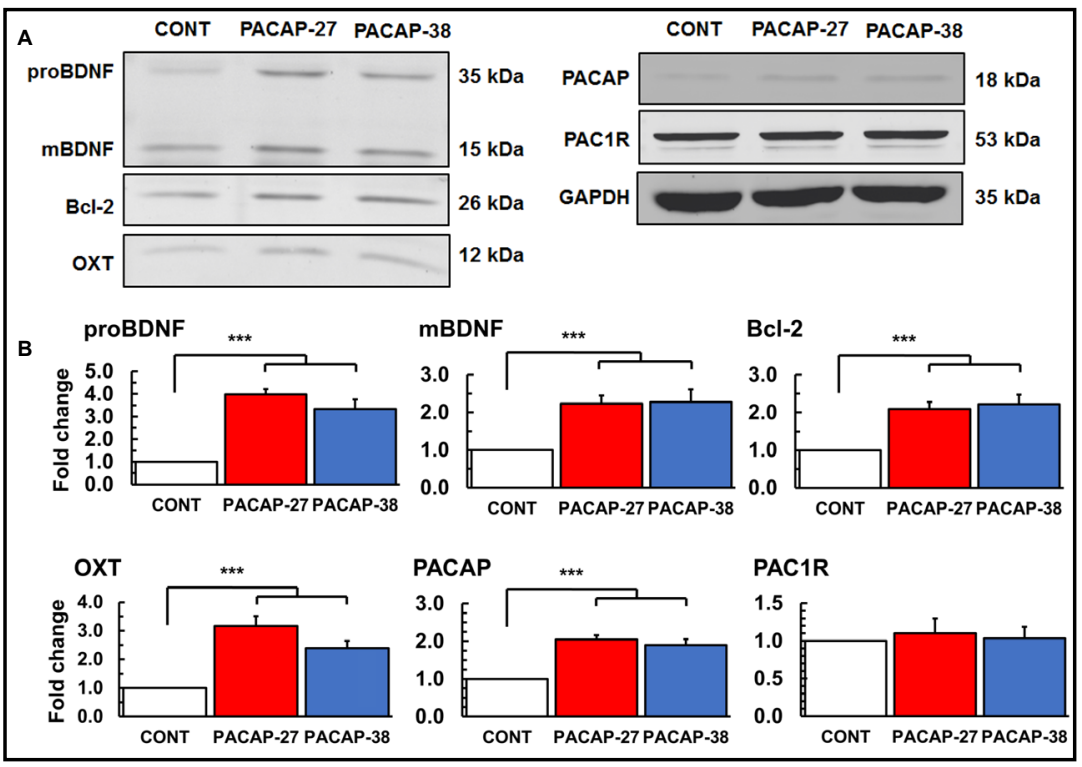

expression levels, but decreased GluN2B and GluN2D subunits. Interestingly, PACAP-27, but not PACAP-38, significantly increased GluN2C subunit expression levels.

\section{Discussion}

The present study revealed a novel molecular mechanism underlying PACAP-mediated neuroprotection against acute ischemic stroke in a cell culture paradigm. We found that PACAP-elicited neuroprotection is associated with repression of apoptotic signaling induced by mitochondrial damage, prevention of HMGB1 secretion, enhancement of neurotrophic factor levels, and reconstitution of NMDAR subunit components in PRNCs.

Ischemic injury is exacerbated by aberrant ROS accumulation, generated primarily by damaged mitochondria [17], which leads to apoptosis and necrosis. During OGD/R, cell viability, mitochondrial activity, and mitochondrial membrane potential were decreased, and GSSG activity and extracellular HMGB1 levels were increased (Fig. 2). Under OGD/R conditions, pretreatment with PACAP-27 and PACAP-38 increased cell viability, mitochondrial activity, and mitochondrial membrane potential, while decreasing GSSG activity and 
preventing HMGB1

secretion from the cell

(Fig. 2). We showed that PACAP-27/38 confers neuroprotection against OGD/R (Fig. 2), and that PACAP-27 ameliorates cell death more than PACAP-38 under OGD/R $\left(E C_{50}\right.$ values, Fig. $2 \mathrm{~A}, a$ vs a). PACAP contributes to neuronal stem cell proliferation [24], energy balance [25], and differentiation $[26,27]$. Cell growth of PRNCs was not affected by PACAP-27/38 (Fig. 5A). We predicted that PACAP-27/38 would affect GSSG activity, mitochondrial membrane potential, and ATP contents in PRNCs, increasing neuroprotection before OGD, but no significances were detected across treatment conditions (Fig. 5B-D), which suggest that PACAP-27/38 treatmentrelated neuroprotection against acute ischemic stroke was distinct from cell proliferation and mitochondrial maintenance signal pathways in PRNCs.

Bcl-2 suppresses the release of cytochrome c from the mitochondria into the cytosol, and prevents the activation of caspase 9 and subsequent cleavage of caspase 3. BDNF plays a critical role in learning and memory, and is essential for synaptic function, plasticity, and neuronal survival. Oxytocin protects against acute ischemia-induced inflammation and oxidative stress, and is associated with GABA ( $\gamma$-aminobutyric acid) signaling transduction in PRNCs [15]. PACAP-27/38 elevated the expression levels of Bcl-2, BDNF, and oxytocin before OGD (Fig. 6), although we could not detect BDNF and oxytocin levels in culture medium (data not shown). These observations indicated that PACAP-27/38 enhanced neuroprotection against acute ischemic stroke via increased expression of neurotrophic factors [28]. Additionally, delivering PACAP38 intranasally in Huntington's disease mouse models mitigated disease-related deficits by restoring cognitive function and PAC1R protein levels, and increasing expression of BDNF and proteins associated with synaptic plasticity [29]. PACAP increases its own expression in an autocrine positive feedback loop [30]. Our results confirmed that PACAP-27/38 increased the expression level of precursor PACAP (Fig. 6). PAC1R plays a pivotal role in the transcriptional regulation of BDNF. However, PAC1R expression levels were not changed by administration of PACAP-27/38 (Fig. 6). These data indicated that PAC1R-mediated signal transduction was attributed to neurotrophic factors' expression, and that the PAC1R expression mechanism independently contributed to differential function of the PACAP-27/38 in PRNCs. 


\section{Cellular Physiology Cell Physiol Biochem 2018;51:1982-1995 \begin{tabular}{ll|l} 
and & DOl: 10.1159/000495722 & $\begin{array}{l}\text { O } 2018 \text { The Author(s). Published by S. Karger AG, Basel } \\
\text { www.karger.com/cpb }\end{array}$ \\
\cline { 2 - 3 }
\end{tabular} \\ Kaneko et al.: PACAP Regulates NMDAR Subunits}

Neuronal cell death after stroke is mediated by the activation of extrasynaptic GluN2Bcontaining NMDARs which inhibit the CREB (cAMP response element-binding protein) and Erk1/2 (extracellular signal-regulated kinase 1 and 2) pathways in addition to directly promoting apoptosis signaling induced by caspase 3 activation [31, 32]. GluN2B subunitcontaining NMDARs mediate brain damage in stroke through intracellular signaling cascades [31]. Our observations suggested that PACAP-27/38 attenuated cytochrome c/ caspase 3 death signaling (Fig. 3 and 4) due in part to decreased expression levels of the GluN2B subunit (Fig. 7). During ischemia/reperfusion, excessive glutamate accumulates in the synaptic cleft and extracellular space of neuronal cells, leading to neuronal cell death [33]. The GluN2D subunit has the highest affinity for glutamate $\left(E C_{50}: 0.4 \mu \mathrm{M}\right)$ compared to the other GluN2 subunits $\left(E C_{50}: 1 \sim 4 \mu \mathrm{M}\right)$ [34]. The NMDARs containing a combination of the GluN1 and GluN2A subunits have the lowest sensitivity to glutamate [35]. PACAP-27/38 robustly increased the GluN1 subunit expression and slightly enhanced the GluN2A subunit expression (Fig. 7). It is conceivable that under pretreatment of PRNCs with PACAP-27/38, an increase in GluN1/GluN2A subunits and decrease in GluN2B/GluN2D subunits may synergistically amplify neuroprotection before OGD.

The NMDAR is a cation channel that binds the neurotransmitter glutamate, and is constitutively deactivated by $\mathrm{Mg}^{2+}$ at resting membrane potential; the " $\mathrm{Mg}^{2+}$ block" [36]. Opening the NMDAR channel requires both glutamate binding to GluN2 subunits and membrane depolarization, which are necessary to remove the $\mathrm{Mg}^{2+}$ block. NMDARs containing GluN2C are more resistant to the $\mathrm{Mg}^{2+}$ block than those containing GluN2A and GluN2B [34, 37]. A GluN2C knockout model demonstrates more vulnerability to neuronal cell damage following ischemia, suggesting that GluN2C has a stronger neuroprotective effect than other GluN2 subunits [38]. BDNF signaling upregulates GluN2C gene expression [39]. BDNF has neuroprotective properties, and can rescue neurons from NMDAR blockadeinduced neuronal cell death [40]. PACAP-27/38 increased the expression levels of both proBDNF and mBDNF (Fig. 6). Interestingly, PACAP-27, but not PACAP-38, significantly increased the expression level of GluN2C (Fig. 7), indicating that PACAP-27 may trigger an alternative signaling pathway promoting neuroprotection, which is emerging as a key factor in neurodegenerative diseases [41, 42].

That PACAP is altered in the present stroke model advances the notion of PACAP's involvement in aging. Of note, aging is major co-morbidity factor of stroke [43,44]. An impaired neurovascular unit has been implicated as a key pathology of stroke $[45,46]$, and aging appears to dampen PACAP expression in the vasculature of mice, rendering the blood supply to the brain vulnerable to stroke $[47,48]$. In other aging-related neurological disorders, such as Alzheimer's disease, pre-senile systemic amyloidosis displayed an accelerated trajectory in PACAP knockout mice, supporting the concept that PACAP may serve a neuroprotective role in age-induced degenerative processes [49], likely via sequestration of $\beta$-amyloid toxicity [50]. Moreover, PACAP-knockout mice exhibit accelerated retinal aging [51]. Such aging-mediated PACAP alteration seen in mice is also observed in aged non-human primates with cognitive impairments [52], suggesting that a deficient PACAP expression pathologically manifests as learning and memory dysfunction. Altogether, in tandem with the present data, PACAP may play a pivotal role in harnessing healthy aging, possibly by nurturing the homeostasis of the neurovascular unit and promoting neuroprotective effects.

A major contributor to neuronal cell death in stroke is excitotoxicity $[1,53,54]$, which results in glutamatergic synapse dysfunction, particularly NMDAR signaling transduction [55]. Of note, inhibiting NMDARs with antagonists such as kynurenic acid, the synthetic analog of kyneuric acid, and MK-801 precluded migraine-related overexpression of PACAP-38 and presumably excessive glutamate release in the trigeminal nucleus caudalis of migraine model rats, suggesting a connection between NMDARs and PACAP expression [56]. While NMDAR antagonists can potentially mitigate glutamate-generated hyperexcitation in migraines and other neuronal maladies [56], they have also been associated with adverse effects such as addiction in rats $[57,58]$. Our data demonstrated that PACAP-27/38 exerted neuroprotection against acute ischemic stroke by shifting the expression of NMDAR subunits. Pilot in vitro 


\section{Cellular Physiology Cell Physiol Biochem 2018;51:1982-1995 \begin{tabular}{l|l|l} 
and Biochemistry Published onlIne:1 1 December 2018 & $\begin{array}{l}\text { @ } 2018 \text { The Author(s). Published by S. Karger AG, Basel } \\
\text { www.karger.com/cpb }\end{array}$ \\
\hline
\end{tabular} \\ Kaneko et al.: PACAP Regulates NMDAR Subunits}

data reveal that PACAP treatment also reduced levels of OGD/R-induced inflammation, including TNF- $\alpha$ expression. Although differences of physiological function and properties between PACAP-27 and PACAP-38 in PRNCs remain unexplored, our study highlights a close interaction between PACAP-27/38 and NMDARs that should advance our understanding of stroke pathology and its treatment.

\section{Acknowledgements}

This study was funded by National Institutes of Health 1R21NS089851 and National Institutes of Health 5R01NS071956. The authors have no ethical conflicts to disclose. Conceptualization, Y.K., X.J., and C.V.B. Methodology, Y.K., J.P.T., X.J., and C.V.B. Investigation, Y.K. and C.V.B. Writing-Original Draft, Y.K. and C.V.B. Writing-Review \& Editing, Y.K., J.P.T., X.J., and C.V.B. Visualization, Y.K., J.P.T., and C.V.B. Funding Acquisition, Y.K. and C.V.B. Resources, Y.K. and C.V.B.

\section{Disclosure Statement}

The authors have no conflicts of interest to declare.

\section{References}

1 Lai TW, Zhang S, Wang YT: Excitotoxicity and stroke: identifying novel targets for neuroprotection. Prog Neurobiol 2014;115:157-188.

-2 Stonesifer C, Corey S, Ghanekar S, Diamandis Z, Acosta SA, Borlongan CV: Stem cell therapy for abrogating stroke-induced neuroinflammation and relevant secondary cell death mechanisms. Prog Neurobiol 2017;158:94-131.

-3 Lo EH: A new penumbra: transitioning from injury into repair after stroke. Nat Med 2008;14:497-500.

- Lu T, Aron L, Zullo J, Pan Y, Kim H, Chen Y, Yang TH, Kim HM, Drake D, Liu XS, Bennett DA, Colaiacovo MP, Yankner BA: REST and stress resistance in ageing and Alzheimer's disease. Nature 2014;507:448-454.

5 Dawson TM, Dawson VL: Molecular pathways of neurodegeneration in Parkinson's disease. Science 2003;302:819-822.

6 Miyata A, Arimura A, Dahl RR, Minamino N, Uehara A, Jiang L, Culler MD, Coy DH: Isolation of a novel 38 residue-hypothalamic polypeptide which stimulates adenylate cyclase in pituitary cells. Biochem Biophys Res Commun 1989;164:567-574.

7 Kimura C, Ohkubo S, Ogi K, Hosoya M, Itoh Y, Onda H, Miyata A, Jiang L, Dahl RR, Stibbs HH, et al.: A novel peptide which stimulates adenylate cyclase: molecular cloning and characterization of the ovine and human cDNAs. Biochem Biophys Res Commun 1990;166:81-89.

$>8$ Arimura A, Somogyvari-Vigh A, Miyata A, Mizuno K, Coy DH, Kitada C: Tissue distribution of PACAP as determined by RIA: highly abundant in the rat brain and testes. Endocrinology 1991;129:2787-2789.

-9 Ohtaki H, Nakamachi T, Dohi K, Aizawa Y, Takaki A, Hodoyama K, Yofu S, Hashimoto H, Shintani N, Baba A, Kopf M, Iwakura Y, Matsuda K, Arimura A, Shioda S: Pituitary adenylate cyclase-activating polypeptide (PACAP) decreases ischemic neuronal cell death in association with IL-6. Proc Natl Acad Sci USA 2006;103:7488-7493.

10 Tan YV, Abad C, Lopez R, Dong H, Liu S, Lee A, Gomariz RP, Leceta J, Waschek JA: Pituitary adenylyl cyclaseactivating polypeptide is an intrinsic regulator of Treg abundance and protects against experimental autoimmune encephalomyelitis. Proc Natl Acad Sci USA 2009;106:2012-2017.

11 Vaudry D, Falluel-Morel A, Bourgault S, Basille M, Burel D, Wurtz O, Fournier A, Chow BK, Hashimoto H, Galas L, Vaudry H: Pituitary adenylate cyclase-activating polypeptide and its receptors: 20 years after the discovery. Pharmacol Rev 2009;61:283-357. 


\section{Cellular Physiology Cell Physiol Biochem 2018;51:1982-1995 \begin{tabular}{ll|l} 
and Biochemistry & $\begin{array}{l}\text { DOI: 10.1159/000495722 } \\
\text { Published online: 1 December } 2018\end{array}$ & $\begin{array}{l}\text { ( } 2018 \text { The Author(s). Published by S. Karger AG, Basel } \\
\text { www.karger.com/cpb }\end{array}$ \\
\hline
\end{tabular} \\ Kaneko et al.: PACAP Regulates NMDAR Subunits}

12 Stumm R, Kolodziej A, Prinz V, Endres M, Wu DF, Hollt V: Pituitary adenylate cyclase-activating polypeptide is up-regulated in cortical pyramidal cells after focal ischemia and protects neurons from mild hypoxic/ ischemic damage. J Neurochem 2007;103:1666-1681.

$\checkmark 13$ Kaneko Y, Tajiri N, Shojo H, Borlongan CV: Oxygen-glucose-deprived rat primary neural cells exhibit DJ-1 translocation into healthy mitochondria: a potent stroke therapeutic target. CNS Neurosci Ther 2014;20:275-281.

14 Kaneko Y, Sullivan R, Dailey T, Vale FL, Tajiri N, Borlongan CV: Kainic acid-induced Golgi complex fragmentation/dispersal shifts the proteolysis of reelin in primary rat neuronal cells: an in vitro model of early stage epilepsy. Mol Neurobiol 2016;53:1874-1883.

15 Kaneko Y, Pappas C, Tajiri N, Borlongan CV: Oxytocin modulates GABAAR subunits to confer neuroprotection in stroke in vitro. Sci Rep 2016;6:35659.

$\checkmark 16$ Choi JY, Cui Y, Chowdhury ST, Kim BG: High-mobility group box-1 as an autocrine trophic factor in white matter stroke. Proc Natl Acad Sci USA 2017;114:E4987-E4995.

17 Fulda S, Galluzzi L, Kroemer G: Targeting mitochondria for cancer therapy. Nat Rev Drug Discov 2010;9:447-464

18 Yamamoto K, Hashimoto H, Tomimoto S, Shintani N, Miyazaki J, Tashiro F, Aihara H, Nammo T, Li M, Yamagata K, Miyagawa J, Matsuzawa Y, Kawabata Y, Fukuyama Y, Koga K, Mori W, Tanaka K, Matsuda T, Baba A: Overexpression of PACAP in transgenic mouse pancreatic beta-cells enhances insulin secretion and ameliorates streptozotocin-induced diabetes. Diabetes 2003;52:1155-1162.

19 Rat D, Schmitt U, Tippmann F, Dewachter I, Theunis C, Wieczerzak E, Postina R, van Leuven F, Fahrenholz F, Kojro E: Neuropeptide pituitary adenylate cyclase-activating polypeptide (PACAP) slows down Alzheimer's disease-like pathology in amyloid precursor protein-transgenic mice. FASEB J 2011;25:3208-3218.

20 El Zein N, Badran B, Sariban E: The neuropeptide pituitary adenylate cyclase activating polypeptide modulates $\mathrm{Ca} 2+$ and pro-inflammatory functions in human monocytes through the G protein-coupled receptors VPAC-1 and formyl peptide receptor-like 1. Cell Calcium 2008;43:270-284.

21 Morio H, Tatsuno I, Hirai A, Tamura Y, Saito Y: Pituitary adenylate cyclase-activating polypeptide protects rat-cultured cortical neurons from glutamate-induced cytotoxicity. Brain Res 1996;741:82-88.

$\checkmark 22$ Chowdhury D, Marco S, Brooks IM, Zandueta A, Rao Y, Haucke V, Wesseling JF, Tavalin SJ, Perez-Otano I: Tyrosine phosphorylation regulates the endocytosis and surface expression of GluN3A-containing NMDA receptors. J Neurosci 2013;33:4151-4164.

23 Pecoraro V, Sardone LM, Chisari M, Licata F, Li Volsi G, Perciavalle V, Ciranna L, Costa L: A subnanomolar concentration of Pituitary Adenylate Cyclase-Activating Polypeptide (PACAP) pre-synaptically modulates glutamatergic transmission in the rat hippocampus acting through acetylcholine. Neuroscience 2017;340:551-562.

24 Matsumoto M, Nakamachi T, Watanabe J, Sugiyama K, Ohtaki H, Murai N, Sasaki S, Xu Z, Hashimoto H, Seki T, Miyazaki A, Shioda S: Pituitary adenylate cyclase-activating polypeptide (PACAP) is involved in adult mouse hippocampal neurogenesis after stroke. J Mol Neurosci 2016;59:270-279.

-25 Rudecki AP, Gray SL: PACAP in the defense of energy homeostasis. Trends Endocrinol Metab 2016;27:620632.

26 Sarkar DK, Boyadjieva NI, Chen CP, Ortiguela M, Reuhl K, Clement EM, Kuhn P, Marano J: Cyclic adenosine monophosphate differentiated beta-endorphin neurons promote immune function and prevent prostate cancer growth. Proc Natl Acad Sci USA 2008;105:9105-9110.

-27 Waschek JA, Cohen JR, Chi GC, Proszynski TJ, Niewiadomski P: PACAP promotes matrix-driven adhesion of cultured adult murine neural progenitors. ASN Neuro 2017;9:1759091417708720.

28 Wang Y, Chang CF, Morales M, Chiang YH, Hoffer J: Protective effects of glial cell line-derived neurotrophic factor in ischemic brain injury. Ann NY Acad Sci 2002;962:423-437.

-29 Cabezas-Llobet N, Vidal-Sancho L, Masana M, Fournier A, Alberch J, Vaudry D, Xifro X: Pituitary adenylate cyclase-activating polypeptide (PACAP) enhances hippocampal synaptic plasticity and improves memory performance in Huntington's disease. Mol Neurobiol 2018;55:8263-8277.

-30 Hashimoto H, Hagihara N, Koga K, Yamamoto K, Shintani N, Tomimoto S, Mori W, Koyama Y, Matsuda T, Baba A: Synergistic induction of pituitary adenylate cyclase-activating polypeptide (PACAP) gene expression by nerve growth factor and PACAP in PC12 cells. J Neurochem 2000;74:501-507.

-31 Hardingham GE, Bading H: Synaptic versus extrasynaptic NMDA receptor signalling: implications for neurodegenerative disorders. Nat Rev Neurosci 2010;11:682-696. 


\section{Cellular Physiology Cell Physiol Biochem 2018;51:1982-1995 \begin{tabular}{l|l|l} 
and Biochemistry Published onlıne: 1 December 2018 & $\begin{array}{l}\text { (c) } 2018 \text { The Author(s). Published by S. Karger AG, Basel } \\
\text { www.karger.com/cpb }\end{array}$ \\
\hline
\end{tabular} \\ Kaneko et al.: PACAP Regulates NMDAR Subunits}

-32 Tu W, Xu X, Peng L, Zhong X, Zhang W, Soundarapandian MM, Balel C, Wang M, Jia N, Zhang W, Lew F, Chan SL, Chen Y, Lu Y: DAPK1 interaction with NMDA receptor NR2B subunits mediates brain damage in stroke. Cell 2010;140:222-234.

33 Bi M, Gladbach A, van Eersel J, Ittner A, Przybyla M, van Hummel A, Chua SW, Hoven JV, Lee WS, Muller J, Parmar J, Jonquieres GV, Stefen H, Guccione E, Fath T, Housley GD, Klugmann M, Ke YD, Ittner LM: Tau exacerbates excitotoxic brain damage in an animal model of stroke. Nat Commun 2017;8:473.

-34 Paoletti P: Molecular basis of NMDA receptor functional diversity. Eur J Neurosci 2011;33:1351-1365.

-35 Paoletti P, Bellone C, Zhou Q: NMDA receptor subunit diversity: impact on receptor properties, synaptic plasticity and disease. Nat Rev Neurosci 2013;14:383-400.

-36 Moriyoshi K, Masu M, Ishii T, Shigemoto R, Mizuno N, Nakanishi S: Molecular cloning and characterization of the rat NMDA receptor. Nature 1991;354:31-37.

-37 Khlestova E, Johnson JW, Krystal JH, Lisman J: The role of GluN2C-containing NMDA receptors in ketamine's psychotogenic action and in schizophrenia models. J Neurosci 2016;36:11151-11157.

-38 Chung C, Marson JD, Zhang QG, Kim J, Wu WH, Brann DW, Chen BS: Neuroprotection mediated through GluN2C-containing N-methyl-D-aspartate (NMDA) receptors following ischemia. Sci Rep 2016;6:37033.

-39 Abe H, Okazawa M, Nakanishi S: Gene regulation via excitation and BDNF is mediated by induction and phosphorylation of the Etv1 transcription factor in cerebellar granule cells. Proc Natl Acad Sci USA 2012;109:8734-8739.

40 Hansen HH, Briem T, Dzietko M, Sifringer M, Voss A, Rzeski W, Zdzisinska B, Thor F, Heumann R, Stepulak A, Bittigau P, Ikonomidou C: Mechanisms leading to disseminated apoptosis following NMDA receptor blockade in the developing rat brain. Neurobiol Dis 2004;16:440-453.

-41 Polanco MJ, Parodi S, Piol D, Stack C, Chivet M, Contestabile A, Miranda HC, Lievens PM, Espinoza S, Jochum T, Rocchi A, Grunseich C, Gainetdinov RR, Cato AC, Lieberman AP, La Spada AR, Sambataro F, Fischbeck $\mathrm{KH}$, Gozes I, Pennuto M: Adenylyl cyclase activating polypeptide reduces phosphorylation and toxicity of the polyglutamine-expanded androgen receptor in spinobulbar muscular atrophy. Sci Transl Med 2016;8:370ra181.

42 Ressler KJ, Mercer KB, Bradley B, Jovanovic T, Mahan A, Kerley K, Norrholm SD, Kilaru V, Smith AK, Myers AJ, Ramirez M, Engel A, Hammack SE, Toufexis D, Braas KM, Binder EB, May V: Post-traumatic stress disorder is associated with PACAP and the PAC1 receptor. Nature 2011;470:492-497.

43 Chen W, Simpson JM, March LM, Blyth FM, Bliuc D, Tran T, Nguyen TV, Eisman JA, Center JR: Comorbidities only account for a small proportion of excess mortality after fracture: a record linkage study of individual fracture types. J Bone Miner Res 2018;33:795-802.

44 Willey JZ, Moon YP, Sacco RL, Greenlee H, Diaz KM, Wright CB, Elkind MS, Cheung YK: Physical inactivity is a strong risk factor for stroke in the oldest old: findings from a multi-ethnic population (the Northern Manhattan Study). Int J Stroke 2017;12:197-200.

45 Maki T, Morancho A, Martinez-San Segundo P, Hayakawa K, Takase H, Liang AC, Gabriel-Salazar M, MedinaGutierrez E, Washida K, Montaner J, Lok J, Lo EH, Arai K, Rosell A: Endothelial progenitor cell secretome and oligovascular repair in a mouse model of prolonged cerebral hypoperfusion. Stroke 2018;49:10031010.

-46 Shindo A, Liang AC, Maki T, Miyamoto N, Tomimoto H, Lo EH, Arai K: Subcortical ischemic vascular disease: roles of oligodendrocyte function in experimental models of subcortical white-matter injury. J Cereb Blood Flow Metab 2016;36:187-198.

-47 Ivic I, Solymar M, Fulop BD, Hashimoto H, Toth G, Tamas A, Juhasz T, Koller A, Reglodi D: Aging-induced modulation of pituitary adenylate cyclase-activating peptide- and vasoactive intestinal peptide-induced vasomotor responses in the arteries of mice. J Vasc Res 2017;54:359-366.

48 Vamos Z, Ivic I, Cseplo P, Toth G, Tamas A, Reglodi D, Koller A: Pituitary adenylate cyclase-activating polypeptide (PACAP) induces relaxations of peripheral and cerebral arteries, which are differentially impaired by aging. J Mol Neurosci 2014;54:535-542.

49 Reglodi D, Jungling A, Longuespee R, Kriegsmann J, Casadonte R, Kriegsmann M, Juhasz T, Bardosi S, Tamas A, Fulop BD, Kovacs K, Nagy Z, Sparks J, Miseta A, Mazzucchelli G, Hashimoto H, Bardosi A: Accelerated pre-senile systemic amyloidosis in PACAP knockout mice - a protective role of PACAP in age-related degenerative processes. J Pathol 2018;245:478-490.

50 Han P, Tang Z, Yin J, Maalouf M, Beach TG, Reiman EM, Shi J: Pituitary adenylate cyclase-activating polypeptide protects against beta-amyloid toxicity. Neurobiol Aging 2014;35:2064-2071. 


\section{Cellular Physiology Cell Physiol Biochem 2018;51:1982-1995

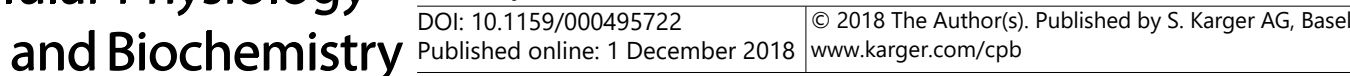

Kaneko et al.: PACAP Regulates NMDAR Subunits

51 Kovacs-Valasek A, Szabadfi K, Denes V, Szalontai B, Tamas A, Kiss P, Szabo A, Setalo G, Jr., Reglodi D, Gabriel R: Accelerated retinal aging in PACAP knock-out mice. Neuroscience 2017;348:1-10.

52 Han P, Nielsen M, Song M, Yin J, Permenter MR, Vogt JA, Engle JR, Dugger BN, Beach TG, Barnes CA, Shi J: The impact of aging on brain pituitary adenylate cyclase activating polypeptide, pathology and cognition in mice and rhesus macaques. Front Aging Neurosci 2017;9:180.

-53 Besancon E, Guo S, Lok J, Tymianski M, Lo EH: Beyond NMDA and AMPA glutamate receptors: emerging mechanisms for ionic imbalance and cell death in stroke. Trends Pharmacol Sci 2008;29:268-275.

54 Zhang F, Xing J, Liou AK, Wang S, Gan Y, Luo Y, Ji X, Stetler RA, Chen J, Cao G: Enhanced delivery of erythropoietin across the blood-brain barrier for neuroprotection against ischemic neuronal injury. Transl Stroke Res 2010;1:113-121.

55 Simon RP, Swan JH, Griffiths T, Meldrum BS: Blockade of N-methyl-D-aspartate receptors may protect against ischemic damage in the brain. Science 1984;226:850-852.

56 Kortesi T, Tuka B, Tajti J, Bagoly T, Fulop F, Helyes Z, Vecsei L: Kynurenic acid inhibits the electrical stimulation induced elevated pituitary adenylate cyclase-activating polypeptide expression in the TNC. Front Neurol 2017;8:745.

57 Botanas CJ, de la Pena JB, Dela Pena IJ, Tampus R, Yoon R, Kim HJ, Lee YS, Jang CG, Cheong JH: Methoxetamine, a ketamine derivative, produced conditioned place preference and was self-administered by rats: evidence of its abuse potential. Pharmacol Biochem Behav 2015;133:31-36.

58 de la Pena JB, de la Pena IJ, Lee HL, de la Pena I, Shin CY, Sohn AR, Cheong JH: Pre-exposure to ethanol, but not to caffeine and nicotine, induced place preference and self-administration of the NMDA receptor antagonist-benzodiazepine combination, Zoletil(R). Pharmacol Biochem Behav 2013;110:231-237. 